\begin{tabular}{lrr}
\hline Volume 21 & Nomor 1, Januari 2020 & Halaman 1-9 \\
URL: https://jurnal.unej.ac.id/index.php/SEMIOTIKA/index & E-ISSN: 2599-3429 & P-ISSN: 1411-5948 \\
\hline
\end{tabular}

\title{
REPRESENTASI NILAI PERJUANGAN \\ DALAM NOVEL BERHENTI DI KAMU KARYA GIA PRATAMA
}

\author{
THE REPRESENTATION OF VALUE OF THE STRUGGLE \\ IN GIA PRATAMA' BERHENTI DI KAMU
}

\author{
Hadi Rumadi \\ Pendidikan Bahasa dan Sastra Indonesia, Universitas Riau \\ Corresponding Author: hadirumadipbsi@gmail.com \\ Informasi Artikel: \\ Dikirim: 28/10/2019; Direvisi: 13/12/2019; Diterima: 3/1/2020
}

\begin{abstract}
Background of this research is about life struggle in the novel entitled Berhenti di Kamu (\#BERHENTIDIKAMU) by Gia Pratama. Values are general guidelines to direct human action refer to good and wrong based on the rules to act according to the rules, whether in religion, moral, or social reflecting the beauty and harmony. The research problem is how to represent the value of the main character's struggle in the novel Berhenti di Kamu. The research aims to describe the importance of the battle of life in the novel Berhenti di Кати. This research's benefit is developing educational theory, especially the idea of values for giving appreciation to the literary works full of life values. This research method is qualitative research. The analysis shows that the importance of struggle is not only physical fighting but also intrapersonal fighting or fighting. Berhenti di Kaти by Gia Pratama explores the internal conflict, which makes the reader perceives the indirect moral lesson. The value of struggle is the outcome of a human's efforts in undergoing the experience, challenges, and problems in life. The importance of conflicts illustrates how big a person's struggle in their life. Human life is inseparable from the human battle itself.
\end{abstract}

Keywords: value struggle, novel, representation

\begin{abstract}
Abstrak
Latar belakang penelitian adalah nilai perjuangan dalam novel Berhenti di Kamu (\#BERHENTIDIKAMU) karya Gia Pratama. Nilai adalah hal-hal yang merujuk pada kebaikan dan keburukan yang berfungsi untuk mengontrol manusia agar bertindak sesuai peraturan, baik dalam agama, moral, sosial yang mencerminkan suatu keindahan dan keselarasan. Rumusan masalah adalah bagaimanakah representasi nilai perjuangan tokoh utama dalam novel Berhenti di Kamu karya Gia Pratama. Tujuan penelitian adalah mendeskripsikan nilai-nilai perjuangan dalam novel Berhenti di Kamu. Manfaat penelitian ini adalah untuk pengembangan teoretis pendidikan khususnya teori nilai sebagai bentuk apresiasi karya sastra yang di dalamnya sarat dengan nilai-nilai kehidupan. Metode penelitian ini merupakan penelitian kualitatif. Hasil analisis menunjukkan bahwa nilai-nilai perjuangan tidak hanya berjuang dalam artian berperang atau memperjuangkan hak-hak dengan cara fisik saja, tetapi perjuangan juga dilakukan di dalam diri seseorang. Nilai-nilai perjuangan ini menunjukkan bahwa novel karya Gia Pratama ini memiliki konflik yang membuat pembaca memahami pesan-pesan moral disampaikan secara tidak langsung, memberikan pelajaran-pelajaran penting melalui novel. Nilai perjuangan merupakan hasil dari usaha seorang manusia dalam menjalani
\end{abstract}


sebuah pengalaman, tantangan, serta permasalahan di dalam hidup. Nilai-nilai perjuangan dapat dijadikan sebagai gambaran betapa besarnya perjuangan sesorang dalam hidup ini. Kehidupan manusia tidak lepas dari perjuangan manusia itu sendiri.

Kata kunci: nilai perjuangan, novel, representasi

\section{PENDAHULUAN}

Karya sastra dapat tercipta karena adanya sesuatu yang menjadikan jiwa seorang pengarang mempunyai rasa tertentu pada permasalahan atau peristiwa di dunia ini. Permasalahan atau peristiwa itu sangat memengaruhi bentuk kejiwaan seorang pengarang dalam mewujudkan karya sastra. Wicaksono (2014) berpendapat bahwa di samping mengekspresikan dan mengungkapkan persoalan yang terjadi, pengarang juga ingin mengajak pembaca untuk berpikir memecahkan permasalahan kehidupan.

Wellek dan Warren (2014) mengemukakan bahwa sastra merupakan karya kreatif yang dapat ditelaah dari berbagai perspektif. Sastra merupakan suatu karya seni dalam eksistensinya bahwa menggunakan bahasa sebagai mediumnya dalam mengungkapkan peristiwa-peristiwa hidup dan kehidupan yang telah terjadi pada masyarakat.

Ada dua unsur yang membentuk karya sastra prosa, yakni unsur ekstrinsik dan unsur intrinsik. Pertama, unsur ekstrinsik adalah unsur yang mempengaruhi penciptaan karya sastra dari luar. Yang termasuk unsur ini adalah hal-hal yang berkaitan dengan unsur sosiologi, ideologi, histori, politik, ekonomi, kebudayaan, dan lain-lain. Kedua, unsur intrinsik. Unsur intrinsik adalah unsur yang membentuk karya sastra dari dalam. Adapun unsur-unsur intrinsik tersebut adalah (1) tema atau inti cerita; (2) tokoh atau perwatakan; (3) alur atau plot; (4) latar atau setting; (5) teknik penceritaan atau pusat pengisahan; dan (6) diksi atau gaya bahasa, (7) amanat cerita (Nurgiyantoro, 2010).

Menurut Nurgiyantoro (2010) novel berasal dari bahasa Italia yakni novella yang berarti sebuah barang baru yang kecil, dan kemudiakan diartikan sebagai 'cerita dalam bentuk prosa'. Dewasa ini istilah novella mengandung pengertian dengan istilah Indonesia 'novelette' (Inggris), yang berarti sebuah karya prosa fiksi yag panjangnya cukupannya, tidak terlalu panjang, namun juga tidak terlalu pendek.

Selanjutnya, Nurgiyantoro (2010) juga mengemukakan bahwa novel adalah media penuangan pikiran, perasaan, dan gagasan penulis dalam merespon kehidupan di sekitarnya. Ketika di dalam kehidupan muncul permasalahan baru, nurani penulis novel novel akan terpanggil unntuk segera menciptakan sebuah cerita. Segi panjang cerita, novel (jauh) lebih panjang daripada cerpen. Oleh karena itu, novel dapat mengemukakan sesuatu secara bebas, menyajikan sesuatu secara lebih banyak, lebih rinci, lebih detil, dan lebih banyak melibatkan berbagai permasalahan yang lebih kompleks.

Berdasarkan pendapat yang dikemukakan tersebut, novel ialah suatu cerita dengan tokoh, alur dan unsur lainnya mengisi satu buku atau lebih yang mengarang kehidupan manusia hingga terjadinya suatu konflik yang menyebabkan adanya perubahan nasib bagi para pelakunya.

Salah satu novel yang mengisahkan perjuangan hidup adalah novel karya dr. Gia Pratama (selanjutnya ditulis Gia Pratama) (2018) berjudul Berhenti di Kamu (dalam buku, judul novel tertulis dengan huruf berikut: \#BERHENTIDIKAMU; untuk selanjutnya, dalam 
artikel ini ditulis menjadi Berhenti di Кати). Novel tersebut mengisahkan romantika perjuangan hidup, termasuk juga terkait persoalan mencari jodoh.

Rumusan masalah pada penelitian ini adalah bagaimanakah representasi perjuangan dalam novel Berhenti di Kamu karya Gia Pratama? Adapun tujuan penelitian ini adalah mendeskripsikan dan menemukan serta memahami nilai-nilai perjuangan pada novel. Penelitian ini bermanfaat untuk pengembangan teoretis dan pengembangan pemahaman memahami teori-teori pada sastra khususnya teori nilai sebagai bentuk apresiasi karya sastra.

Sanusi (2015) berpendapat bahwa nilai adalah sistem berdasarkan komponenkomponen yang berinteraksi, berinterelasi, dan berinterkoneksi. Melalui pengertian tersebut maka nilai adalah hal-hal yang merujuk pada kebaikan dan keburukan yang berfungsi untuk mengontrol manusia agar bertindak sesuai peraturan, baik dalam agama, moral, sosial yang mencerminkan suatu keindahan.

Perjuangan merupakan suatu usaha yang dilakukan dengan sekuat tenaga untuk memeroleh sesuatu yang sukar diperoleh. Perjuangan yang akan menjadi kajian dalam novel penelitian ini adalah perjuangan yang dilakukan oleh tokoh utama dalam novel Berhenti di Kamu dalam menghadapi masalah yang dihadapinya.

Joyomartono (1990) menjelaskan bahwa suatu nilai dapat berfungsi sebagai pedoman tertinggi perilaku manusia. Nilai selalu menyangkut pertimbangan baik dan tidak baik tentang sesuatu yang selanjutnya dijadikan pegangan, dijadikan pedoman dan dasar dilakukannya suatu tindakan. Di tengah-tengah kehidupan masyarakat yang terus berkembang, nilai juga pasti akan ikut berkembang dan akhirnya akan berubah.

Nilai-nilai perjuangan biasanya akan ditunjukkan oleh seseorang ketika dia mendapatkan suatu masalah di dalam kehidupannya. Orang tersebut akan melakukan perjuangan dengan tujuan agar dapat lepas dari masalah itu dan dengan harapan bisa mendapatkan kehidupan yang lebih baik lagi. Nilai-nilai perjuangan akan mendorong lahirnya suatu sikap mental yang baru, dan yang selanjutnya membimbing orang tersebut untuk melakukan suatu tindakan baru yang lebih baik dari upaya menghadapi dan menyelesaikan masalah kehidupan yang sedang dihadapinya.

Nilai-nilai perjuangan merupakan suatu nilai yang melekat pada masyarakat kita sejak dulu. Secara sadar atau tidak sadar nilai ini akan timbul atau lahir begitu saja ketika kita menghadapi suatu masalah. Besarnya masalah kehidupan yang dialami oleh tokoh utama membuatnya harus melakukan perjuangan yang besar pula. Tokoh utama menunjukkan nilai perjuangan dalam perbuatan dan usaha untuk melewati masalah kehidupan yang menghampirinya.

Perjuangan dapat dimaknai sebagai perkelahian merebut sesuatu, usaha yang penuh dengan kesukaran dan bahaya, atau salah satu wujud interaksi sosial, termasuk persaingan, pelanggaran, konflik. Perjuangan tidak terlepas dari masalah struktur sosial yang mendukungnya.

\section{METODE}

Jenis penelitian ini merupakan penelitian kualitatif. Penelitian ini menitikberatkan pada segi alamiah dan mendasarkan pada karakter tokoh utama yang terdapat dalam novel Berhenti di Kamu karya Gia Pratama. Metode penelitian yang digunakan dalam penelitian ini adalah metode deskriptif, karena peneliti mendeskripsikan menganalisis nilai-nilai perjuangan 
dalam novel tersebut. Objek penelitian ini adalah nilai-nilai perjuangan yang terkandung dalam novel Berhenti di Kamu karya Gia Pratama. Data penelitian ini adalah data berupa kata, kalimat dalam bentuk ungkapan, dialog antartokoh yang menunjukkan adanya konflik kejiwaan dalam memperjuangkan suatu tujuan yang terjadi pada tokoh.

Untuk memperoleh data penelitian, penulis menerapkan teknik dokumentasi dan kepustakaan dalam menganalisis ujaran nilai-nilai perjuangan tokoh utama di dalam novel. Cara ini dioperasionalkan melalui pengumpulan data yang relevan dengan masalah penelitian. Unsur bahasa dibaca, dipahami, dan ditelaah melalui pendekataan teori nilai secara cermat sehingga memperoleh hasil penelitiaan deskripsi nilai-nilai perjuangan. Teknik dokumentasi yang penulis maksud adalah dengan menggunakan tabel klasifikasi dan tabel rekapitulasi. Teknik ini dimanfaatkan sebagai sarana mengumpulkan hasil penelitian.

\section{HASIL DAN PEMBAHASAN}

Penelitian ini mengungkapkan nilai perjuangan dalam novel Berhenti di Кати berdasarkan penafsiran kata-kata, kalimat dan dialog-dialog percakapan antartokoh yang ada di dalam novel. Penulis mengutip metafor yang dituliskan pada novel secara keseluruhan dan menyesuaikannya dengan indikator-indikator sehingga mengarah kepada makna nilai perjuangan. Berdasarkan 12 data pada tabel, terdapat nilai-nilai yang berkaitan dengan nilai perjuangan tokoh utama pada novel, baik yang diungkapkan melalui dialog percakapan tokoh atau kejadian-kejadian yang tedapat di dalam novel. Berikut rekapitulasi dan deskripsi data hasil penelitian yang berkaitan dengan nilai-nilai perjuangan. Data ini juga digunakan sebagai instrumen nilai perjuangan tokoh utama dalam berbagai kejadian kepada hal-hal yang bersifat membangun dalam konsep perjuangan.

Tabel. Data Nilai Perjuangan

\begin{tabular}{|c|c|c|c|}
\hline No. & Data & Halaman & Nilai Perjuangan \\
\hline 1. & $\begin{array}{l}\text {..."Saya beristighfar. Mana mungkin saya } \\
\text { mengajaknya berkenalan di Hijr Ismail? Ini } \\
\text { area ibadah. Tanpa menghiraukan perempuan } \\
\text { tadi, saya keluar dari area itu. Saat keluar, saya } \\
\text { mendengar sekilas dia berbicara dengan } \\
\text { serombongannya. Berbahasa anak Jakarta } \\
\text { banget. Wah,satu daerah, nih.... }\end{array}$ & 28 & Menahan diri \\
\hline 2. & $\begin{array}{l}\text {..."Pa, Aa tuh sampai umur segini belum pernah } \\
\text { dugem, lho." Dunia Saya sejak kecil hanyalah } \\
\text { rumah dan sekolah. Setiap hari pukul } 21.00 \\
\text { saya sudah mengantuk dan tidur. Saya tak } \\
\text { pernah bermalam mingguan di luar layaknya } \\
\text { anak muda lain. Saya bukan anak gaul seperti } \\
\text { Elsa....." }\end{array}$ & 69 & Teguh pendirian \\
\hline 3. & $\begin{array}{l}\text { “...Saya mengusap peluh di dahi. Untuk } \\
\text { memastikan kondisi Ibu Karmiti, saya meminta } \\
\text { perawat melakukan analisis gas darah untuk } \\
\text { memastikan oksigen benar-benar masuk ke } \\
\text { dalam darah dan karbon dioksida keluar dari } \\
\text { darah. Ternyata hasil tes itu menakjubkan. }\end{array}$ & 119 & $\begin{array}{c}\text { Perjuangan dan } \\
\text { semangat pantang } \\
\text { menyerah }\end{array}$ \\
\hline
\end{tabular}


Dilakukan MRI ulang, gumpalan darah di batang otaknya sudah hilang dan terserap kembali oleh tubuh".....

4. “... Kadang untuk pasien saja kita harus menggali lebih dalam tentang banyak informasi, apalagi sama pasangan. Tapi, masalahnhya enggak banyak yang saya mengerti tentang Elsa sebulan ini. Semoga nanti di Eropa kita bisa melepas rindu dan barbagi ribuan informasi seperyi yang biasa kita lakukan ...."

5. ... Saya mulai emosi dan dalam hati berteriak, "kamu mau coba bikin aku marah?" sebetulya setelah dari Eiffel, saya sudah tak bersemangat menjelaskan apa pun kepada rombongan. Saya maunya diam dan tak peduli. Tapi, saya tak bisa bersikap begitu. Saya harus menghargai keluarga Elsa. Terpaksa saya tak menghiraukan suasana hati sendiri karena harus menjelaskan kepada keluarga saya dan keluarga Elsa ...

6. "Kayaknya kita temenan aja, deh. . .”. “ Ucapannya membuat jantung saya berhenti beberapa detik. Napas saya tercekat. Rasanya seperti terkena lima buah tombak yang menusuk sekaligus..."

7. ... "Saya mengumpulkan kembali serpihan diri saya, lalu berdiri, menarik napas dalam-dalam, berjalan menuju kereta gantung, masih dengan tatapan kosong mirip zombie. Saya turun gunung, lalu naik bus menuju hotel.” ..

8. ... "Gi, separah-parahnya masalah fisik dan mental yang mendera, bumi tidak peduli! Ia tetap berputar pada porosnya dan tetap mengelilingi matahari. Jadi, kamu juga harus tetap 'berputar'. Harus segera move on" ....

9. ... "Saya nggak tau sama sekali isi hati Fira yang sesungguhnya. Ini baru pertemuan kedua saya dengan Fira. Saya hanya berbekal percakapan harian saya selama ini dan keyakinan keteguhan hasil shalat istikharah. Saya benar-benar pasrah dan berserah kepadaNya da hanya bisa berharap dia merasakan hal yang sama."....

10. ... "Dari hasil percakapan saya degan Fira, saya tahu kalau Fira juga tengah meminta petunjuk kepada Allah megenai jodohnya. Dia mendekatkan diri kepada Allah, salah satunya dengan Istiqamah melaksanakan shalat Dhuha setiap hari sebanyak 12 rakaat.”...

11. ... "Saya shalat istikharah beberapa kali,
Perjuangan dan semangat pantang menyerah

Menahan amarah

Perjuangan dan semangat pantang menyerah

Perjuangan dan semangat pantang menyerah

Bangkit dari keterpurukan

Perjuangan dalam penantian

Perjuangan dalam penantian 
hasilnya hati saya lebih dimantapkan lagi. Tanpa keraguan, pada Januari tahun selanjutnya saya melamar Syafira untuk menjadi istri saya."...

12 .. Dan tentang masa lalu, saya tidak bisa menghapusnya. Saya percaya kepedihan itu memang harus terjadi. Yang bisa saya lakukan hanya menulis ulang cerita baru di atas cerita kepedihan ... penantian kebahagiaan

Berdasarkan 12 data yang di dapat dari kutipan-kutipan di dalam novel Berhenti di Kamu karya Gia Pratama yang diterbitkan pada tahun 2018, terdapat beragam makna-makna yang merujuk pada nilai perjuangan tokoh. Penafsiran nilai data di atas merupakan sebuah bentuk pesan-pesan atau nilai-nilai moral perjuangan yang terdapat di dalam novel. Pemaknaan nilai-nilai perjuangan dikaji dari berbagai sudut pandang sehingga dapat diperoleh makna-makna sebenarnya yang sesuai dengan nilai-nilai perjuangan. Oleh karena itu, penulis mempertimbangkan dalam aspek ulasan deskripsi memaparkan nilai-nilai perjuangan apa saja yang tercantum pada data. Penulis hanya memaparkan tujuh data mengingat kasus dan nilai yang terkandung sama. Berikut adalah deskripsi data penelitian tentang 7 nilai-nilai perjuangan pada novel dari 12 data penelitian yang diambil dari 19 bab pada novel Berhenti di Кати.

\section{Nilai Perjuangan dalam Menahan diri}

Nilai perjuangan dalam menahan diri ini berdasarkan kutipan novel halaman 28 . Dalam kutipan novel ini di sebutkan bahwa tokoh utama Gia, menginginkan untuk berkenalan dengan Elsa di Hij'r Ismail sebuah tempat suci yang terdapat di kota mekah. Dari kutipan novel tersebut dapat diketahui bahwa kecenderungan Gia untuk berjuang menahan diri untuk berkenalan di tempat suci yang digunakan untuk orang beribadah. Dalam hal ini, nilai perjuangan adalah menahan dari gejolak keinginan diri untuk melakukan hal yang dirasa kurang pantas untuk dilakukan. Lebih luasnya, nilai perjuangan dalam menahan diri ini di definisikan sebagai bentuk perjuanagan mempertahankan prinsip serta menghormati tempattempat ibadah untuk menjaga hal-hal yang tidak diinginkan terjadi.

\section{Nilai Teguh Pendirian}

Teguh pendirian pada novel Berhenti di Катu diperlihatkan oleh tokoh utama pada novel halaman 69, yang diucapkan tokoh utama ketika berbincang dengan sang ayah mengenai pergaulannya yang tidak pernah dugem, dan dunia sejak kecilnya hanyalah rumah dan sekolah, dan tidak pernah keluar untuk bermalam mingguan layaknya anak muda lain. Dari kutipan tersebut diketahui bahwa tokoh utama memiliki nilai teguh pendirian untuk mempertahankan prinsip yang diajarkan kedua orang tua. Dalam hal ini, nilai teguh pendirian merupakan suatu komitmen pada diri sendiri yang harus dipertahankan serta jangan sampai goyah dengan pembicaraan orang-orang di luar sana. 


\section{Nilai Sabar dan Semangat Pantang Menyerah}

Nilai sabar dan semangat pantang menyerah ini muncul dan terkandung di dalam beberapa kutipan novel seperti pada data, pada salah satu penggalan atau kutipan novel halaman 177, tokoh utama bersabar dan mengumpulkan kembali serpihan hatinya yang telah dipatahkan oleh sang kekasih yang tiba-tiba memutuskan hubungan keduanya. Tokoh utama kemudian bangkit dari keterpurukan dan pantang menyerah terhadap keadaan perih yang telah dialaminya. Perjuangan tokoh utama diperlihatkan dengan tetap diam dan menerima semua keputusan kekasih, ini sebuah perjuangan untuk tidak marah. Pantang menyerah merupakan suatu kunci untuk mendapatkan kesuksesan dalam suatu perjuangan.

\section{Nilai Perjuangan Menahan Amarah atau Emosi}

Pergolakan batin Gia di dalam novel yang menunujukkan bahwa ia berusaha untuk menahan amarah. Nilai-nilai Perjuangan menahan amarah ini terdapat pada kutipan pada novel halaman 167, yang menggambarkan suasana hati seorang Gia yang mulai jengah dengan tingkah laku Elsa yang mengacuhkannya saat liburan, menganggap Gia tidak ada disekitarnya, "kamu mau coba bikin aku marah?!" ucapan batin Gia ini merupakan bentuk bahwa ia menahan sekuat tenaga semua amarah. Dalam hal ini, dapat diambil amanat yang terkandung bahwa menahan amarah lebih baik dari pada marah yang akan merugikan.

\section{Nilai Perjuangan Bangkit dari Keterpurukan}

Pada novel Berhenti di Kamu, terdapat konflik-konflik serta kejadian yang dilalui oleh tokoh utama. Dalam hal ini, tentu tokoh utama pernah berada di kondisi tersulit, seperti pada kutipan halaman 218 pada novel, yang menunjukkan bahwa sang tokoh utama menguatkan dirinya sendiri dan bangkit dari keterpurukan karena kejadian masa lalunya. Gia memahami bahwa bumi akan terus berputar tidak peduli kondisi seseorang. Oleh karena itu, ia harus move on dari mantan dan mencari kebahagiaan lain. Jadi, yang dilakukan tokoh utama adalah bangkit dari keterpurukan agar bisa belajar bagaimana menjadi sosok yang lebih tangguh dalam menjalani kehidupan selanjutnya. Pelajaran yang dapat diambil, jangan lagi mengeluh dengan setiap masalah yang menimpa.

\section{Nilai Perjuangan dalam Penantian}

Perjuangan dalam penantian yakni, pada kutipan novel terdapat gambaran tokoh utama yang tengah memperjuangkan jodohnya pada halaman 251. Pada kutipan tersebut, dijelaskan bahwa tokoh utama, Gia dan Fira meminta petunjuk kepada Allah mengenai jodoh. Mendekatkan diri dengan istiqomah melaksanakan shalat dhuha setiap hari sebanyak12 rakaat. Ini menjelaskan bahwa ada nilai-nilai Perjuangan dalam penantian yakni berjuang melalui pendekatan dengan sang pencipta pemilik semesta. Agar Gia dan Fira yakin mengenai jodoh. Hal ini tentu menjadikan pelajaran bahwa segala sesuatu telah ditentukan oleh pencipta dan tergantung bagaimana ikhtiar untuk yang terbaik dalam hidup, ini berkaitan dengan nilainilai religius serta urusan kayakinan.

\section{Nilai Perjuangan Meraih Kebahagiaan}

Nilai-nilai perjuangan meraih kebahagiaan, pada novel jelas diketahui terdapat konflik-konflik yang menguras emosi para penikmat karya sastra. Dalam novel yang telah 
diteliti tentu ada perjuangan-perjuangan tokoh untuk meraih kabahagiaan. Novel Berhenti di Кати ini bergenre romantis dengan akhir yang bahagia. Jadi, tentu sebelum akhir yang bahagia tokoh terlebih dahulu mengalami konflik-konflik yang menyedihkan. Seperti pada kutipan halaman 277 yang menjelaskan bahwa tokoh utama yang telah meraih kebahagian dengan istri tanpa menghapus kenangan-kenangan masa lalu yang menyakitkan, yang dia lakukan adalah menulis ulang kisah baru yang membahagiakan. Gia Pratama, penulis novel menunjukkan bahwa kebahagiaan itu harus diraih dan diperjuangkan tidak hanya berpangku tangan.

Berdasarkan hasil penelitian mendeskripsikan bahwa nilai-nilai perjuangan tidak hanya berjuang dalam artian berperang atau memperjuangkan hak-hak dengan cara fisik saja, tetapi perjuangan juga dilakukan di dalam diri seseorang tersebut, seperti yang telah penulis jelaskan. Adanya nilai-nilai perjuangan ini menunjukkan bahwa novel karya Gia Pratama ini memiliki konflik yang membuat pembaca memahami pesan-pesan moral disampaikan secara tidak langsung, memberikan pelajaran-pelajaran penting melalui novel.

Besarnya masalah kehidupan yang dialami oleh tokoh utama membuatnya harus melakukan perjuangan yang besar pula. Tokoh utama menunjukkan nilai-nilai perjuangan dalam perbuatan dan usaha untuk melewati masalah kehidupan yang menghampirinya. Nilai sangat berkaitan dengan kebaikan yang ada dalam inti sesuatu. Nilai perjuangan berkaitan dengan konflik-konflik serta penyelesaian masalah. Bagaimana pemecahan masalah tersebut menjadikan nilai perjuangan itu diperlukan dalam setiap kondisi. Baik itu konflik batin ataupun konflik yang nyata terjadi dan dapat dilihat.

Nilai perjuangan merupakan hasil dari usaha seorang manusia dalam menjalani sebuah pengalaman, tantangan, serta permasalahan di dalam hidup. Nilai-nilai perjuangan dapat dijadikan sebagai gambaran betapa besarnya Perjuangan sesorang dalam hidup ini. Kehidupan manusia tidak lepas dari perjuangan manusia itu sendiri. Prinsip perjuangan hidup itu berupa tindakan yang nyata. Yang dimaksud dengan aspek perjuangan dalam konteks ini adalah jiwa, tindakan atau aksi nyata, dan semangat yang ditunjukkan oleh tokoh utama dalam novel Berhenti di Kamu, dan nilai-nilai perjuangan yang dilakukan oleh seorang tokoh utama yaitu Gia. Tentu saja, hakikat perjuangan ini sebagai modal utama seseorang dalam menggapai citacita dan harapannya dalam menggapai sesuatu yang diinginkan.

\section{SIMPULAN}

Berdasarkan keseluruhan data yang diambil serta ulasan, dapat disimpulkan bahwasannya nilai-nilai dalam novel Berhenti di Кати ini mengandung nilai-nilai perjuangan yang dapat diterapkan di kehidupan nyata sehari-hari yakni nilai perjuangan dalam menahan diri, teguh pendirian, nilai sabar dan pantang menyerah, Perjuangan bangkit dari keterpurukan, serta nilai Perjuangan dalam penantian. Semua nilai-nilai perjuangan bermanfaat bagi penyelesaian masalah yang telah dihadapai tokoh utama. Nilai-nilai perjuangan inilah yang membuat Gia dapat menyelesaikan masalahnya.

Dalam berbagai konflik yang terjadi pada novel, nilai-nilai perjuangan ini mengungkapkan bahwa perjuangan dapat dilakukan oleh siapa saja, dan karena hal apa saja. Baik melalui perjuangan batin atau tindakan nyata. Pada novel ini, nilai perjuangan tokoh utama yang menjadi sasaran utama penelitian. Pada novel-novel romantis ini terdapat nilainilai perjuangan yang membuat pembaca dapat mengambil amanat dari nilai-nilai perjuangan 
setiap tokoh dalam cerita. Bahwa perjuangan merupakan suatu kegigihan dan kesungguhan dalam menggapai sesuatu sehingga tercapai tujuan yang diinginkan sehingga mendapat peraihan hasil dari perjuangan tersebut. Dengan demikian, nilai-nilai perjuangan pada novel ini dimaksudkan agar setiap pembaca mengambil pelajaran dari perjuangan-perjuangan tokoh utama sebagai implementasi pembaca dalam kehidupan sehari-hari melalui cerita dalam novel.

\section{DAFTAR PUSTAKA}

Joyomartono, M. 1990. Jiwa, Semangat, dan Nilai-nilai Perjuangan Bangsa Indonesia. Semarang: IKIP Semarang Press.

Nurgiyantoro. 2010. Teori Pengkajian Fiksi. Yogyakarta: Gadjah Mada University Press.

Pratama, G. 2018. \#BERHENTIDIKAMU. Jakarta: Mizania.

Sanusi, A.. 2015. Sistem Nilai Alternatif: Wajah-wajah Pendidikan. Bandung: Nuansa Cendikia.

Wellek, R. dan Warren, A. 2014. Teori Kesusastraan. Jakarta: Gramedia.

Wicaksono, A. 2014. Pengkajian Prosa Fiksi. Bandar Lampung: Garudhawacana. 